\title{
Un enfoque alternativo para tomar en cuenta el efecto de la direccionalidad sísmica
} An alternative approach to consider the effect of seismic
directionality

S. Diaz ${ }^{1} * * *$, L. Pujades *, L. Pinzón *, Y. Vargas *

* Universidad Politécnica de Cataluña, Barcelona. ESPAÑA

** Universidad Juárez Autónoma de Tabasco, Tabasco. MEXICO

Fecha de Recepción: 29/01/2018

Fecha de Aceptación: 31/05/2018

PAG 279-290

\begin{abstract}
Recent researches have proven the importance of considering the seismic directionality effect. The performance of buildings subjected to earthquakes depends on its orientation respect to the seismic actions applied. This type of calculation is computed using the nonlinear dynamic analysis (NLDA) and rotating the acceleration horizontal components onto all non-redundant angles, which entails a high computational cost. This paper presents an alternative approach to consider the directionality effect. The method is based on the nonlinear static analysis (NLSA) and in the energy balance between the capacity curves and the response spectra of the rotated seismic actions. This approach was applied to a 4-story steel frame building 3D-model with ground motions records from Mexico City. A high variability in the building performance is observed due to the incidence angle of the seismic action; the proposed method would allow considering this variation in the structural analysis, in an easy way, demanding less calculation time and providing results compatible with those obtained through the NLDA.
\end{abstract}

Keywords: Directionality effect, nonlinear static analysis, capacity curve, response spectrum, seismic performance

\section{Resumen}

Investigaciones recientes han mostrado la importancia de considerar el efecto de direccionalidad sísmica. El desempeño de los edificios sometidos a sismos, dependen de la orientación que el edificio tenga con respecto a las acciones sísmicas aplicadas. Este tipo de análisis se suele realizar usando análisis dinámico no lineal (ADNL) y rotando las componentes horizontales de aceleración para todos los ángulos no redundantes, lo que conlleva un elevado costo computacional. Este artículo presenta un enfoque alternativo para considerar el efecto de direccionalidad. El método se basa, en el análisis estático no lineal (AENL) y en el balance energético entre la curva de capacidad y el espectro de respuesta para hallar el punto de capacidad por demanda. Este método se aplica a un edificio de pórticos de acero de 4 niveles que se modela en 3D y se somete a acciones sísmicas probables en la Ciudad de México. Se observa una alta variabilidad del desempeño del edificio en función del ángulo de entrada de la acción sísmica; el método alternativo supondría tener en cuenta esta variación en el análisis estructural, de forma más sencilla, con un menor tiempo de cálculo y proporcionando resultados compatibles con los obtenidos ADNL.

Palabras clave: Efecto de direccionalidad, análisis estático no lineal, curva de capacidad, espectro de respuesta, desempeño sísmico

\section{Introduction}

In recent studies, such as Vargas et al. (2012) and Vargas et al. (2017), the directionality effect of earthquakes has been evaluated from two approaches: (1) the seismic hazard (Boore et al., 2006; Hong et al., 2009; Boore, 2010; Pinzón et al. 2015) and (2) the expected seismic performance and damage in buildings (Rigato and Medina, 2007; Lagaros, 2010). The first approach refers to the influence that the sensor orientation has on the ground motion predictive equations (GMPE). This effect is shown in Figure 1. In this Figure, the $N-S$ and $E-W$ accelerograms corresponding to the record of the Mexico earthquake of September 19, 1985, registered in the SCT station (MEX85 SCT) of Mexico City are displayed. It is observed that the maximum PGA does not occur for any of the two individual components, but, as observed in the particle movement, this is obtained by combining both components and is given for a specific angle. Nowadays, the GMPE have been updated with new intensity measures (IM) (Boore et al., 2006, Boore 2010) that consider this effect, in the United States (Power et al., 2008, Bozorgnia et al., 2014) and in Mexico (Hong et al., 2009). By studying these effects, it is possible to improve the definition of the seismic hazard in sites with high seismicity.

\footnotetext{
${ }^{1}$ Corresponding author:

Universidad Juárez Autónoma de Tabasco, Tabasco. MEXICO

E-mail: Alberto.diaz@ujat.mx
} 


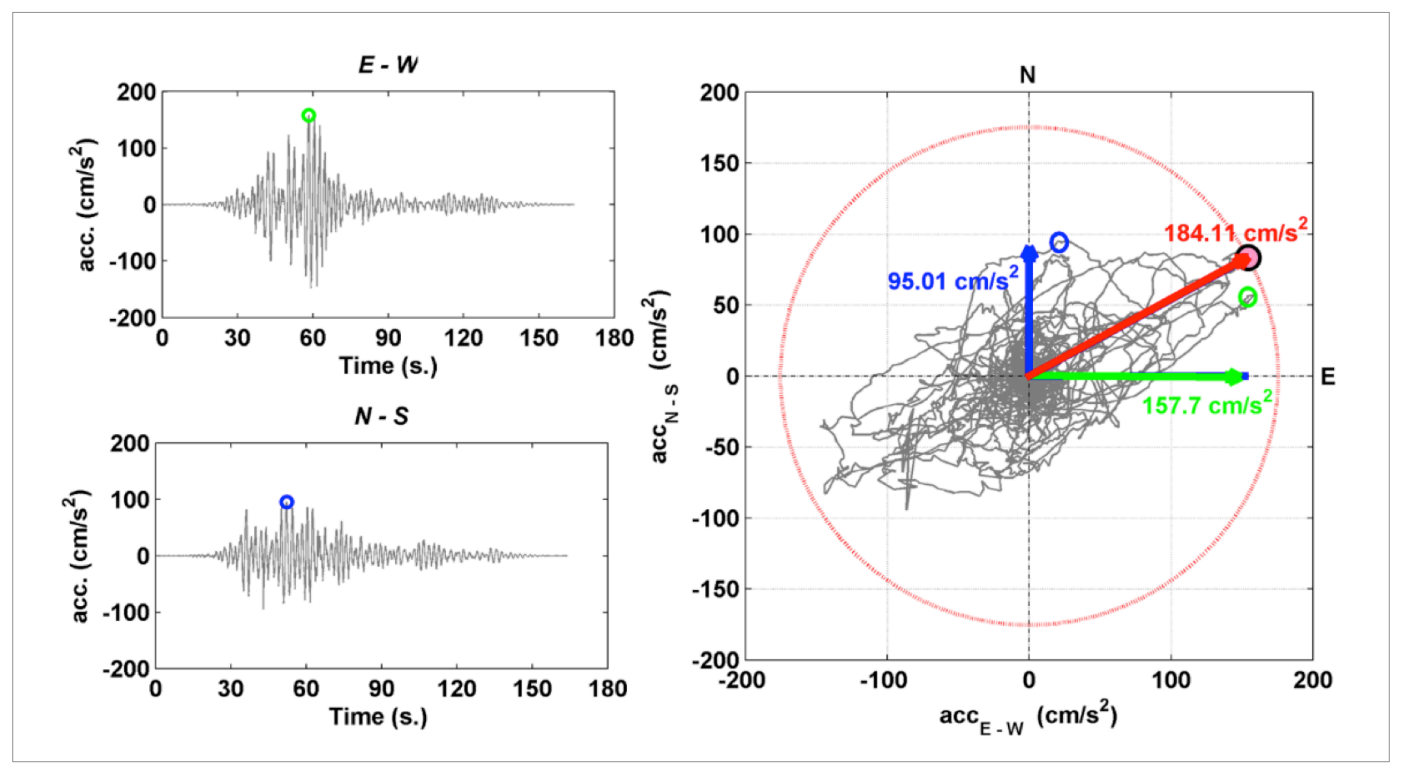

Figure 1. N-S and E-W acceleration horizontal components corresponding to the earthquake of Mexico City (Sept. 19, 1985), recorded in SCT station

The second approach studies the variation of the seismic performance of a building depending on the orientation that it has respect to the applied ground motion record. Recent research has shown that the maximum ductility demand in the displacement of an elastoplastic system with a single-degree-of-freedom (García-Soto et al., 2012), and the maximum displacement response and expected damage of a specific building (Vargas et al., 2012; Kostinakis et al., 2015; Reyes-Salazar et al., 2016; Kostinakis and Morfidis, 2017), can be presented for a different angle of incidence. This shows that the effect of directionality also has an influence on the structural response of a building. This effect can be studied by the following steps: (i) 3D model of a building; (ii) nonlinear dynamic analysis (NLDA); (iii) the asrecorded horizontal components ( $\mathrm{acC}_{\mathrm{N}-\mathrm{S}}$ and $\mathrm{acC}_{\mathrm{E}-\mathrm{W}}$ ) of an earthquake are applied in the main directions of the building; iv) the previous step is repeated by rotating the horizontal components degree to degree from $0^{\circ}$ to $180^{\circ}$ if the structure is regular and from $0^{\circ}$ to $360^{\circ}$ if it is irregular, ie $180 \mathrm{NLDA}$ or 360 NLDA are made respectively. The rotated horizontal components $(\operatorname{accx}(\vartheta)$ and $\operatorname{accy}(\vartheta))$ as a function of asrecorded components (acc $\mathrm{N}_{\mathrm{N}-\mathrm{S}}$ and $\mathrm{acC}_{\mathrm{E}-\mathrm{W}}$ ) are obtained with the following Equation:

$$
\begin{aligned}
& \operatorname{accx}(\theta) \\
& \operatorname{accy}(\theta)
\end{aligned}=\left[\begin{array}{ll}
\cos (\vartheta) & \sin (\vartheta) \\
-\sin (\vartheta) & \cos (\vartheta)
\end{array}\right] *\left[\begin{array}{c}
\operatorname{acc}_{N-S} \\
\operatorname{acc}_{E-W}
\end{array}\right] \quad \theta=1^{\circ} \ldots N^{\circ}
$$

As a result of the directionality analysis, relationships in function of an output variable are obtained, such as the roof displacement $(\delta)$, the base shear or the expected damage in depending on the rotation angle ( $\vartheta)$. Greater displacements, shears and damages are obtained to those estimated with the as-recorded (non-rotated) components in a 3D analysis (Vargas et al., 2012; Vargas et al., 2017), however, the high computational cost implies multiple dynamic analyzes and make difficult the implementation of this effect.

In this paper, only the directionality effect on the expected performance of buildings is studied. For this reason, two approaches are developed: 1) an alternative technic based on nonlinear static analysis (NLSA) and an energy balance (EB) (Mezzi et al., 2006; Leelataviwat et al., 2009; Diaz et al., 2017b) between the capacity spectrum and the response spectrum to find the performance point; and 2) using the NLDA. For both approaches, a 3D model of a 4story steel building with a structural system of special moment frames, SMF, is used as a case of study.

\section{Directionality effect on buillings}

This section shows the directionality effect on buildings, understood as the effect of the variation of seismic performance of the building depending on the orientation of the building respect to the applied ground motion record. This effect is developed from two approaches: (1) using a technic based on the nonlinear static analysis (NLSA) and energy balance $(E B)$, to find the performance point and (2) with NLDA.

The evaluation of directionality in the performance of buildings with both approaches is exemplified in the case of a 4-level steel building, with special moment frames (SMF) of wide-flange beams/columns sections. The connections between the elements are fully rigid (FR) prequalified (ANSI/AISC 358-10, 2010). The building was designed as an office building in Mexico City and complies with the specifications of the NTC-DF (2004) and ANSI/AISC 341-10 (2010) codes. The building model is shown in Figure 2. 


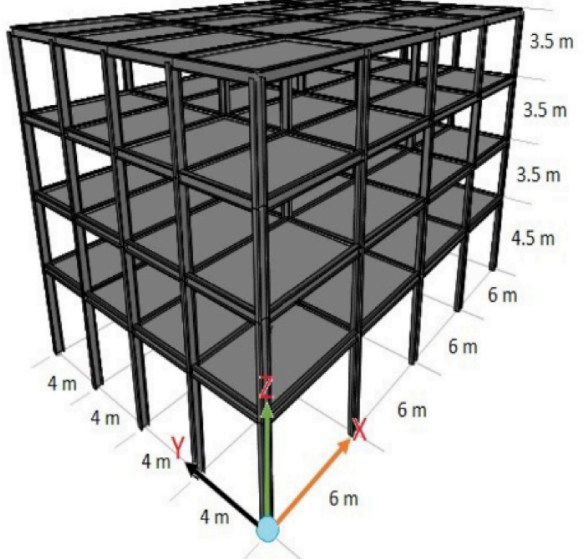

(a)

\begin{tabular}{|c|c|c|c|}
\hline Columns & W16X89 & Beams & $14 \times 68$ \\
\hline $\mathrm{tw}(\mathrm{mm})$ & 13.3 & tw (mm) & 10.5 \\
\hline$d(m m)$ & 425 & $\mathrm{~d}(\mathrm{~mm})$ & 357 \\
\hline $\mathrm{Fy}(\mathrm{MPa})$ & 375.76 & Fy (MPa) & 375.76 \\
\hline $\mathrm{tf}(\mathrm{mm})$ & 22.2 & $\mathrm{tf}(\mathrm{mm})$ & 18.3 \\
\hline bf (mm) & 263 & bf (mm) & 255 \\
\hline
\end{tabular}

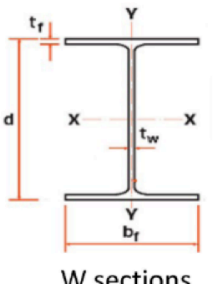

(b)

Figure 2. 3D model used to evaluate the directionality effect (b) beam and column sections

The building was modeled using the program Ruaumoko 3D (Carr, 2002), where the behavior of the beams and columns have been defined based on the resistanceductility relationship of the modified Ibarra-MedinaKrawinkler (IMK) model (Ibarra et al., 2005; Lignos and Krawinkler, 2011; Lignos and Krawinkler, 2013). The modified IMK model of each structural element is adapted to the bilinear hysteresis hardening and ductility degradation law used by the program Ruaumoko 3D through the procedure proposed by Diaz et al. (2017b) The main characteristics of the modal analysis of the building $\left(P F_{1}\right.$, modal participation factor of the fundamental period, $T_{1}, W$ the weight of the structure and the coefficient of participation of the modal mass of the fundamental period of vibration, $\alpha_{1}$ ) are shown in Table 1.
In both approaches, the seismic action has been defined from real accelerograms (horizontal components) and their respective response spectra. Using the technic of Vargas et al. (2013) of compatibility between response spectra and a target spectrum in a Mexico City earthquake database analyzed by Diaz et al. (2017b), 4 ground motion records with a response spectrum compatible with the design spectrum of zone IIla of the NTC-DF code (NTC-DF 2004) of Mexico City are selected. Their main characteristics are presented in Table 2 and their respective response spectra normalized with the highest PGA of the horizontal components corresponding to each earthquake (indicated in red in Table 2) are shown in Figure 3.

Table 1. Values $T 1, W, P F 1$ y $\alpha 1$ from the studied building of Figure 1

\begin{tabular}{|c|c|c|c|c|}
\hline Direction & $\begin{array}{c}\text { Fundamental } \\
\text { Period } \boldsymbol{T}_{\mathbf{1}} \text { (s.) }\end{array}$ & $\begin{array}{c}\text { Total Weight } \\
\boldsymbol{W}(\mathbf{k N})\end{array}$ & $\boldsymbol{P F}_{\mathbf{1}}$ & $\boldsymbol{\alpha}_{\mathbf{1}}$ \\
\hline$X$ & 0.89 & 12,460 & 1.28 & 0.881 \\
\hline$Y$ & 1.04 & 12,460 & 1.20 & 0.885 \\
\hline
\end{tabular}


Table 2. Main characteristics of the selected ground motions from the Mexico City database corresponding to IIla zone

\begin{tabular}{|c|c|c|c|c|c|c|c|c|c|}
\hline ZONE & $\#$ & Station ${ }^{(1)}$ & Date & $\begin{array}{l}\text { Duration } \\
\text { (s) }\end{array}$ & $M w^{(2)}$ & $\begin{array}{c}P G A N-S \\
\left(\mathrm{~cm} / \mathrm{s}^{2}\right)\end{array}$ & $\begin{array}{c}P G A E-W \\
\left(\mathrm{~cm} / \mathrm{s}^{2}\right)\end{array}$ & $\begin{array}{c}\text { Epi. } \\
\text { Dist. }^{(3)}\end{array}$ & Azimut $^{(4)}$ \\
\hline \multirow{4}{*}{ IIIa } & 1 & HJ72 & $18 / 04 / 14$ & 167.47 & 7.2 & 33.20 & 32.19 & 331.1 & 221.4 \\
\hline & 2 & ALO1 & $18 / 04 / 14$ & 165.77 & 7.2 & 28.87 & 37.00 & 330.9 & 221.0 \\
\hline & 3 & TL55 & $30 / 09 / 99$ & 173.86 & 5.5 & 28.80 & 15.62 & 447.6 & 149.7 \\
\hline & 4 & MJSE & 15/06/99 & 144.01 & 7.0 & 17.70 & 13.76 & 222.3 & 128.8 \\
\hline $\begin{array}{l}\text { (1) } A c i \\
\text { (2) } M c \\
\text { (3) } E p i \\
\text { (4) } A z\end{array}$ & & $\begin{array}{l}\text { of accele } \\
\text { nagnitude } \\
\text { distance }\end{array}$ & $\begin{array}{l}\text { netric } s \\
\text { acceler }\end{array}$ & in Mex & & 1 & 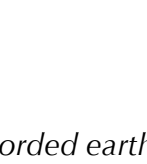 & & \\
\hline
\end{tabular}

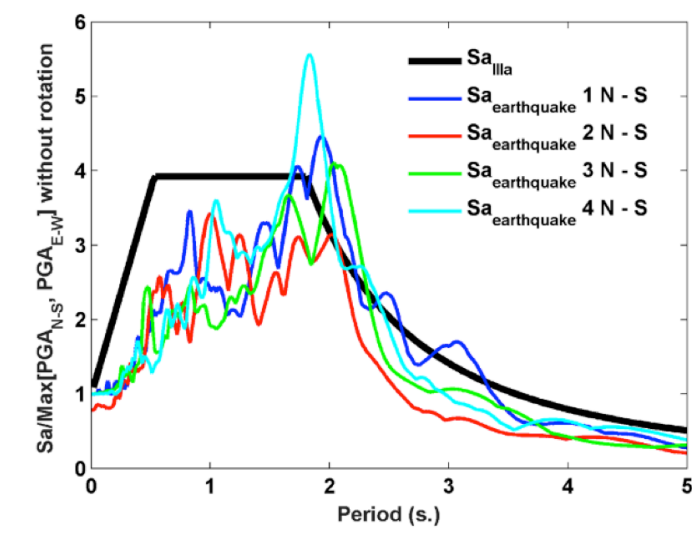

(a) N-S component

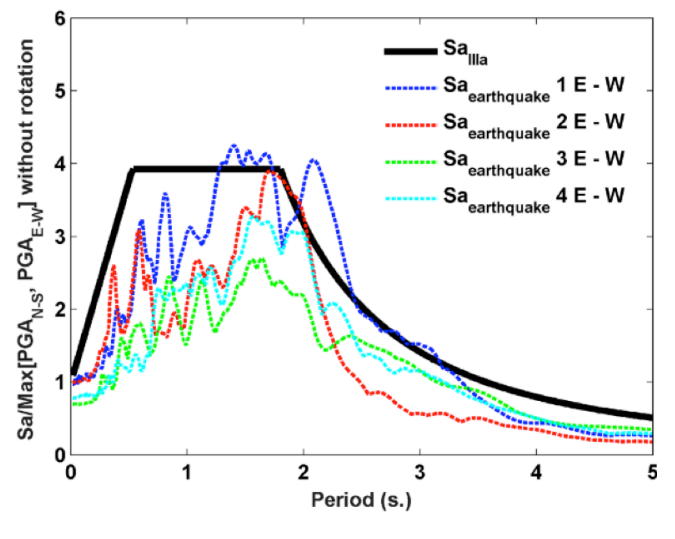

(b) E-W component

Figure 3. Response spectra for the 4 selected earthquakes of Mexico City 


\subsection{Alternative method}

First, the alternative approach is performed. A general diagram of the proposed method is shown in Figure 4, showing the step by step procedure:.

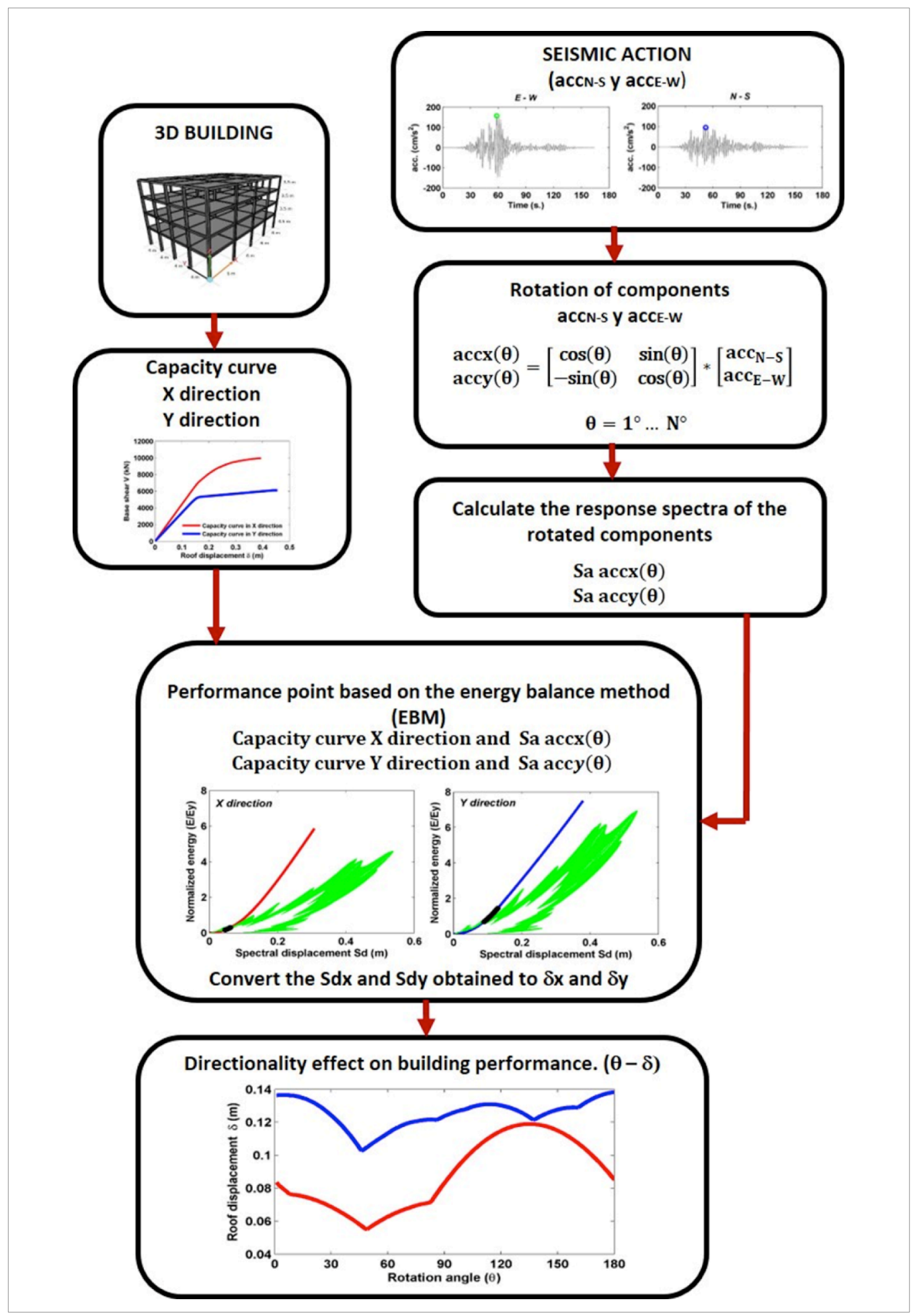

Figure 4. Alternative technic to consider the variation of the seismic performance of the building depending on the orientation that it has respect to a determined seismic action. (Sept. 19, 1985), recorded in SCT station 
1. The NLSA was performed obtaining the capacity curves of the main directions of the building ( $X$ and $Y)$. For this, the adaptive pushover (AP) method (Satyarno, 2000) included in the program
Ruaumoko 3D (Carr, 2002) has been used. However, conventional pushover can also be used. The capacity curves are shown in Figure 5.

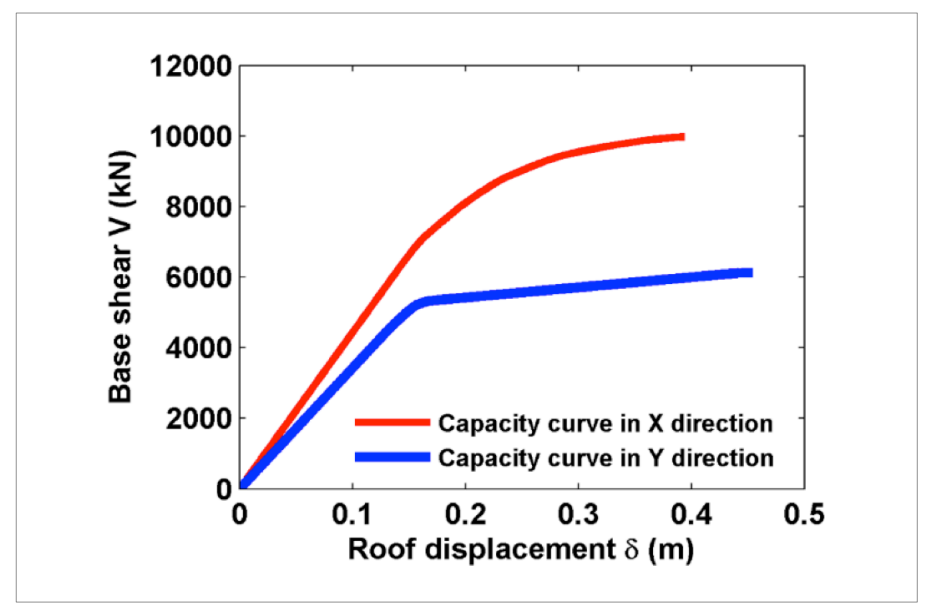

Figure 5. Capacity curves in principal directions of the building ( $X$ and $Y$ )

2. The rotated components (accx $(\vartheta)$ and accy $(\vartheta)$ ) of each earthquake are obtained with Equation 1. In this study, the building has symmetry, so the two horizontal components of each earthquake are rotated degree to degree from $0^{\circ}$ to $180^{\circ}$.

3. The response spectrum of the rotated components

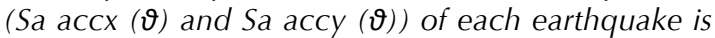
calculated.

4. The set of Sa accx $(\vartheta)$ and Sa accy $(\vartheta)$ of each earthquake are normalized by their respective largest PGA of the two as-recorded components (highest PGA NS and EW of each earthquake marked red in Table 2). The normalization manages to maintain the relations between the two horizontal components of the same record and the relation of each as-recorded component with its respective rotated components. As an example, the response spectra of the earthquake 2 are shown in Figure 6 and in Figure 7 the spectral acceleration variation in

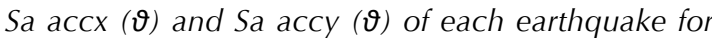
the period $T=O \mathrm{~S}$., equivalent to the PGA of the earthquake and for the fundamental periods of each main direction of the building $T 1 x=0.89 \mathrm{~s}$. and T1y $=1.04 \mathrm{~s}$. is shown. The variation in the spectral acceleration can be related to the seismic performance of the building depending on the orientation that it has respect to the seismic action applied. In Table 3 we show the angle where the maximum spectral acceleration is generated in Sa $\operatorname{accx}(\vartheta)$ and Sa accy $(\vartheta)$ of each earthquake for $T=$ 0 s., T1x and T1y. On the other hand, with the

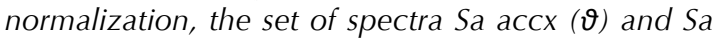

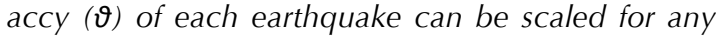
required PGA. For this study, two PGA are used. The first is $0.12 \mathrm{~g}$ so that the performance of the building is in its linear range and the second of 0.22 $g$ so that the performance of the building is in the non-linear range. 


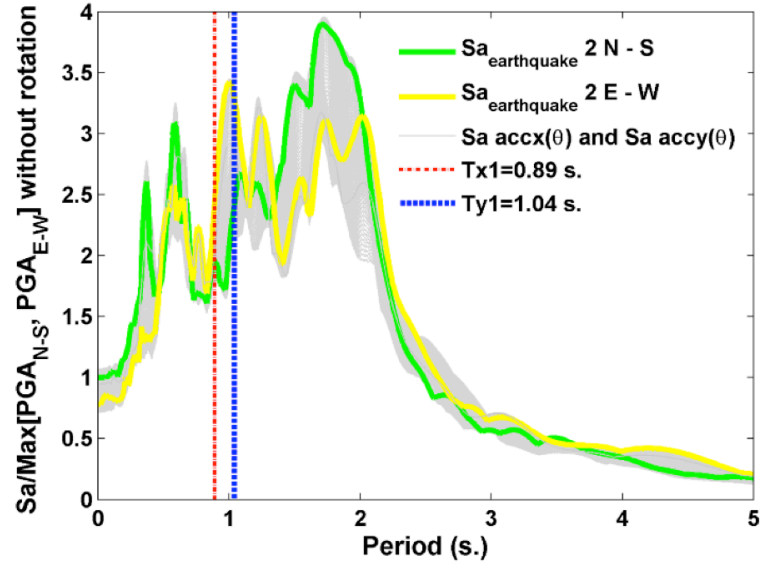

Figure 6. Response spectra of the as-recorded components compared with the rotated (Sa $\operatorname{accx}(\vartheta)$ and Sa accy $(\vartheta)$ ) from earthquake 2. Also, the two fundamental periods (Tx1 and Ty1) of the studied building, corresponding to the main directions ( $X$ and $Y$ ) are plotted

Table 3. Angle where the maximum spectral acceleration is presented in Sa accx ( $)$ and Sa accy ( $\vartheta$ of each earthquake for $T=0$ s., T1x and T1y

\begin{tabular}{|c|c|c|c|c|}
\hline \multirow[t]{2}{*}{ Earthquake } & \multicolumn{2}{|c|}{ 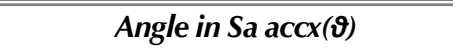 } & \multicolumn{2}{|c|}{ Angle in Sa accy(७) } \\
\hline & $T x=0$ s. o PGAX & $T 1 x=0.89 \mathrm{~s}$ & $T y=0$ s. o PGAy & $T 1 y=1.04 \mathrm{~s}$ \\
\hline 1 & $51^{\circ}$ & $137^{\circ}$ & $141^{\circ}$ & $8^{\circ}$ \\
\hline 2 & $35^{\circ}$ & $19^{\circ}$ & $125^{\circ}$ & $99^{\circ}$ \\
\hline 3 & $11^{\circ}$ & $146^{\circ}$ & $101^{\circ}$ & $132^{\circ}$ \\
\hline 4 & $82^{\circ}$ & $131^{\circ}$ & $172^{\circ}$ & $93^{\circ}$ \\
\hline
\end{tabular}
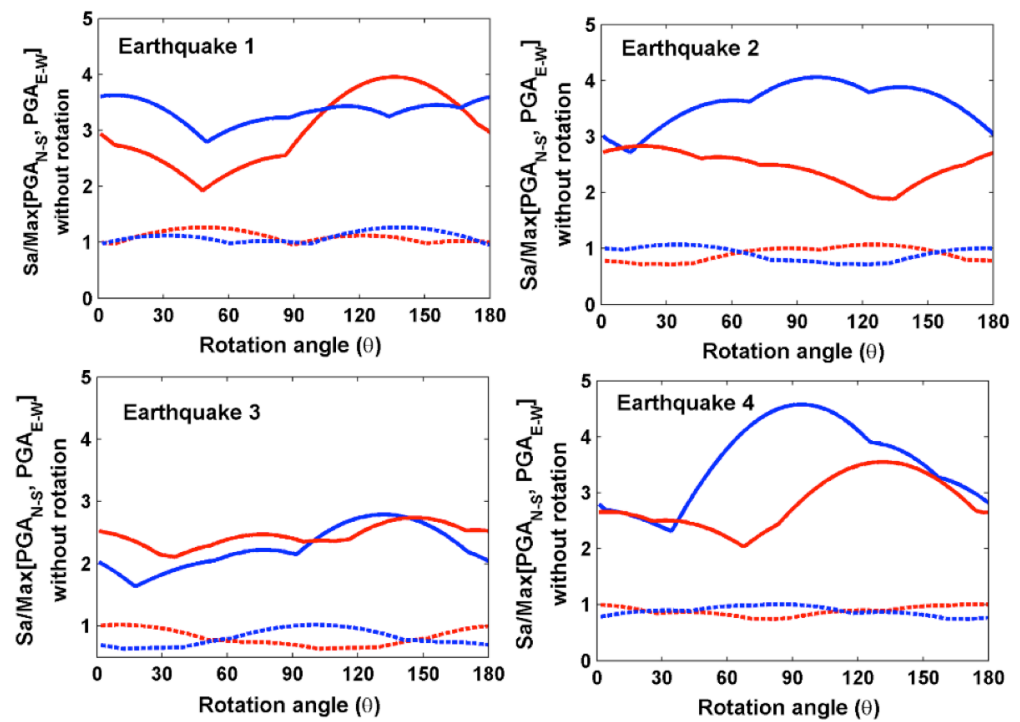

Figure 7. Variation of the spectral acceleration as a function of the rotation angle $(\vartheta)$ for $T=0 \mathrm{~s}$. $(P G A)$ and for the periods $T x 1=0.89 \mathrm{~s}$. and Ty $1=1.04 \mathrm{~s}$. in the spectra Sa accx $(\vartheta)$ and Sa accy (७) of each earthquake 
5. We obtain the roof displacement, $\delta$ of the performance point (PP) in the capacity curves $X$ and $Y$ for its respective set of Sa accx $(\vartheta)$ and Sa accy $(\vartheta)$ of each earthquake. In this approach, the energy balance (EB) (Mezzi et al., 2006; Leelataviwat et al., 2009; Diaz et al., 2017b) is used to cross the capacity and demand spectra. However, any other technic can be used to estimate the PP that is considered adequate for the type of structure. The $E B$ method is based on the relation between the energy response spectrum of the accelerogram $\left(S a_{E}\right)$ and the capacity curve, converted to Energy Accumulated by Deformation (EAD). Both curves must be expressed in spectral - energy displacement $(S d-E)$ normalized by the energy at the yielding point of the capacity curve (Ey). The energy response spectrum $S a_{E}$ is obtained with the equations proposed by Chopra and Goel (2002) and Lee et al. (2004); while the EAD curve is defined as the area under the capacity curve $F(\xi)$, with the Equation 2:

$$
\begin{aligned}
& E A D(\delta)=\int_{0}^{\delta} F() d \quad 0 \leq \leq \delta_{u} ; \quad 0 \leq \\
& E A D(\delta) \leq E A D\left(\delta_{u}\right)
\end{aligned}
$$

In this curve, the roof displacement $(\delta)$ must be converted to spectral displacement by the relation $S d=\delta / P F_{1}$. Further details of these energy functions and how the demand-capacity point is calculated are described in the research by Leelataviwat et al. (2009) and Diaz et al. (2017b). An example of the result of applying this technic is shown in Figure 8. Also, the $\delta P P$ can be obtained by applying the capacity spectrum method (CSM) proposed in the ATC-40 (1996) and in the FEMA273 (1997).

6. The previous step was applied to the 4 scaled earthquakes for the two chosen PGAs (0.12 and $0.22 \mathrm{~g}$ ). The values of the roof displacement $\delta$ in function of the rotation angle $\theta$, corresponding to the performance point $(P P)$ are obtained. The results are shown in Figure 9.

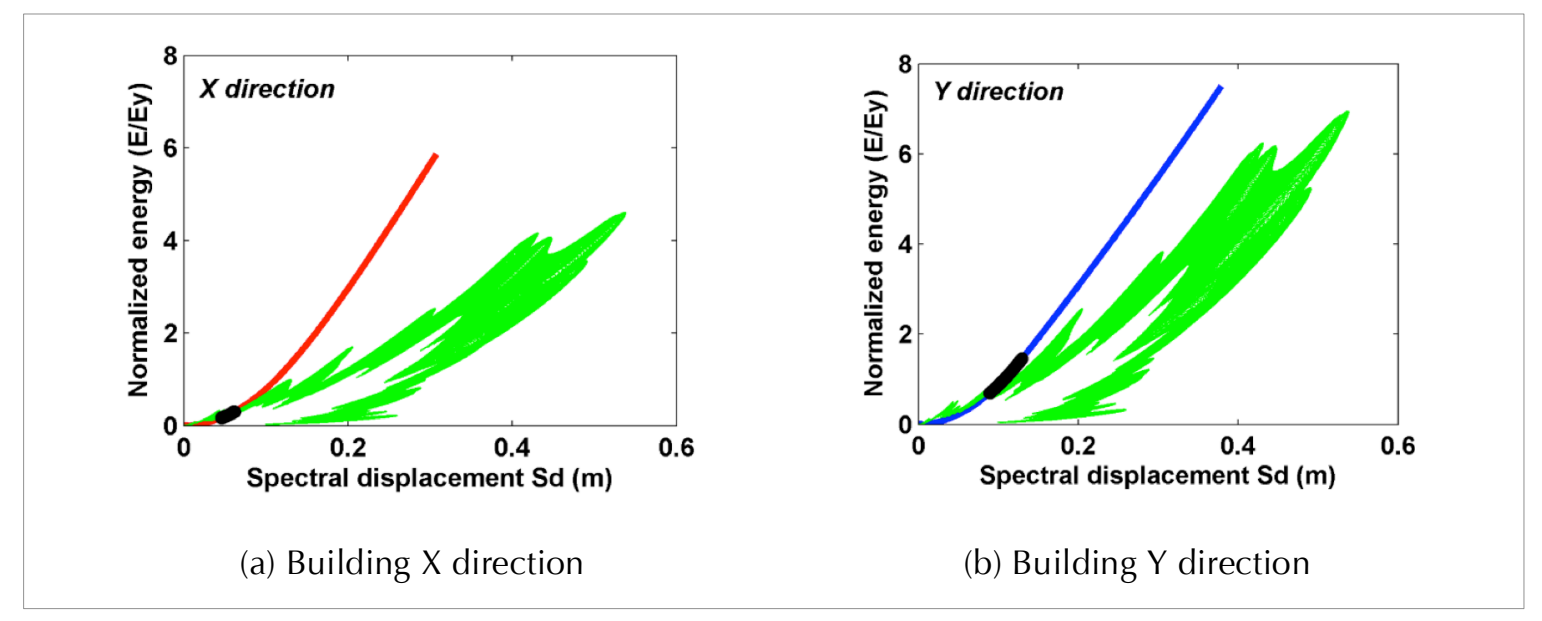

Figure 8. ample of the EB method for EAD curves with Sa accx $(\vartheta)$ and Sa accy $(\vartheta)$ of earthquake 2 scaled for a PGA of $0.12 \mathrm{~g}$

\subsection{Nonlinear dynamic analysis}

In this section, the analysis of the effect of the orientation of the building on its performance is computed, using the nonlinear dynamic analysis, NLDA. In this approach, the horizontal components of each earthquake are rotated from 0 to $180^{\circ}$ with increments of $1^{\circ}$, following the Equation 1 and are introduced one by one into the NLDA. The analysis is also performed for the 4 earthquakes scaled for the two chosen PGAs $(0.12 \mathrm{~g}$ and $0.22 \mathrm{~g})$ in the alternative method. The values of roof displacement $\delta$ in function of the angle of rotation $\vartheta$ are obtained. The results are also shown in Figure 9. These are comparable with those obtained with the alternative technic. Table 4 shows the angles in which the largest displacements in the building are obtained for the Sa $\operatorname{accx}(\vartheta)$ and Sa accy $(\vartheta)$ of each earthquake with the NLDA. Finally, Table 5 shows, for the 8 cases studied (2 PGA intensities $x 4$ earthquakes) the maximum roof displacement, max. $\delta$ and the roof displacement $\delta$ obtained with the asrecorded (non-rotated) components.

Comparing the Table 3 and Table 4 shows that the angle where is obtained the greatest spectral acceleration for the period $T=O \mathrm{~s}$, differs from the angle at which the greatest displacement is presented in the principal directions ( $X$ and $Y$ ) of the building; otherwise with the angle determined for the greater acceleration for the periods T1x and T1y, its seen that they are similar with the angle of the greatest displacement in $X$ and $Y$ respectively, especially in the cases where the structure is in the nonlinear zone, that is practically the same angle. In some cases, significant increases of up to a $42 \%$ in the expected displacements are obtained, if the effect of the orientation of the building on its performance is considered (see Table 5). 
Table 4. Angle where the greatest displacement in $X$ and $Y$ directions is presented considering the effect of the orientation in the building performance with NLDA

\begin{tabular}{|c|c|c|c|c|}
\hline \multirow{2}{*}{ Earthquake } & \multicolumn{2}{|c|}{$P G A=0.12$ g (linear zone) } & \multicolumn{2}{c|}{$\begin{array}{c}\text { PGA }=0.22 \text { g (nonlinear } \\
\text { zone) }\end{array}$} \\
\cline { 2 - 5 } & $\boldsymbol{X}$ & $\boldsymbol{Y}$ & $\boldsymbol{X}$ & $\boldsymbol{Y}$ \\
\hline $\mathbf{1}$ & $136^{\circ}$ & $6^{\circ}$ & $108^{\circ}$ & $0^{\circ}$ \\
\hline $\mathbf{2}$ & $19^{\circ}$ & $99^{\circ}$ & $12^{\circ}$ & $157^{\circ}$ \\
\hline $\mathbf{3}$ & $148^{\circ}$ & $132^{\circ}$ & $147^{\circ}$ & $136^{\circ}$ \\
\hline $\mathbf{4}$ & $130^{\circ}$ & $84^{\circ}$ & $132^{\circ}$ & $99^{\circ}$ \\
\hline
\end{tabular}

Table 5. Comparison of the greatest displacement in $X$ and $Y$ with the displacement of the nonrotated components obtained with the NLDA

\begin{tabular}{|c|c|c|c|c|c|c|c|c|}
\hline \multirow[b]{2}{*}{ \# } & \multicolumn{4}{|c|}{$P G A=0.12 \mathrm{~g}$ (linear zone) } & \multicolumn{4}{|c|}{$P G A=0.22 \mathrm{~g}$ (nonlinear zone) } \\
\hline & $\begin{array}{c}\delta_{P P} \\
\max X \\
(m)\end{array}$ & $\begin{array}{c}\delta_{P P} \\
X \text { non- } \\
\text { rotated } \\
(m)\end{array}$ & $\begin{array}{c}\delta_{P P} \\
\max Y\end{array}$ & $\begin{array}{c}\delta_{P P} \\
Y \text { non- } \\
\text { rotated } \\
(m)\end{array}$ & $\begin{array}{c}\delta_{P P} \\
\max X \\
(m)\end{array}$ & $\begin{array}{c}\delta_{P P} \\
X \text { non- } \\
\text { rotated } \\
(m)\end{array}$ & $\begin{array}{c}\delta_{P P} \\
\max Y\end{array}$ & $\begin{array}{c}\delta_{P P} \\
Y \text { non- } \\
\text { rotated } \\
(m)\end{array}$ \\
\hline 1 & 0.119 & 0.0835 & 0.1366 & 0.1363 & 0.1897 & 0.1661 & 0.2112 & 0.2112 \\
\hline 2 & 0.0781 & 0.0756 & 0.1551 & 0.1140 & 0.1409 & 0.1354 & 0.2084 & 0.1911 \\
\hline 3 & 0.0771 & 0.0703 & 0.1044 & 0.0734 & 0.1412 & 0.1253 & 0.1616 & 0.1217 \\
\hline 4 & 0.0950 & 0.0767 & 0.1654 & 0.1062 & 0.1544 & 0.1429 & 0.2260 & 0.1774 \\
\hline
\end{tabular}




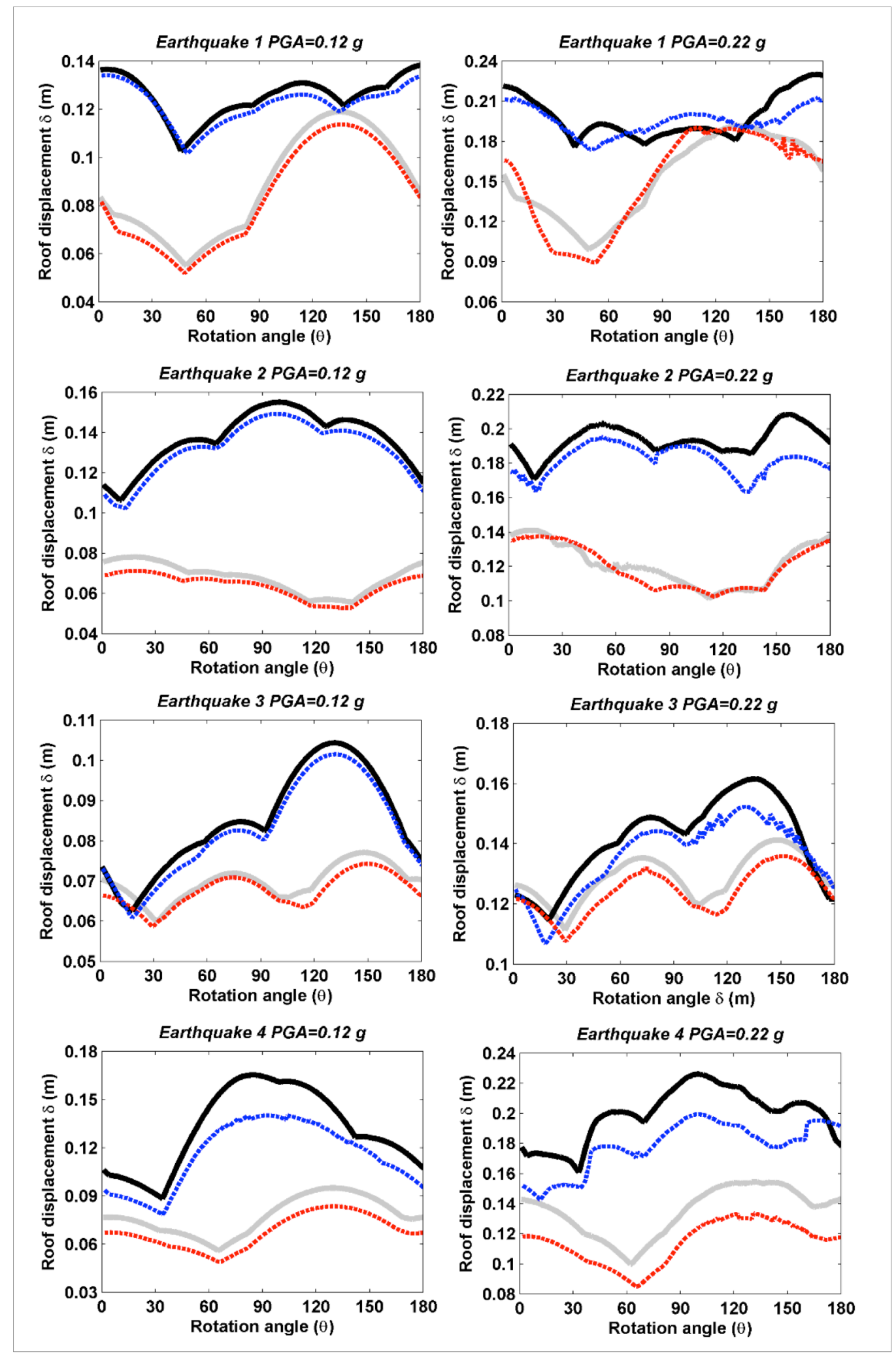

Figure 9. Relationship obtained with the analysis of directionality using the alternative technic and the NLDA for the 4 scaled earthquakes (PGA of $0.12 \mathrm{~g}$ and $0.22 \mathrm{~g}$ ) 


\section{Discussion}

From the study presented in this paper, the following relevant results are obtained: (i) comparing the results of the alternative method, based on the NLSA, with those obtained through NLDA, two aspects stand out: (1) in the linear zone (for a PGA of $0.12 \mathrm{~g}$ ) there is a good agreement between the results of the NLSA and the NLDA and (2) in the nonlinear zone (for a PGA of $0.22 \mathrm{~g}$ ) the agreement is lower (there are some differences in the displacements obtained); in any case, the effect of the orientation of the building respect to the seismic action is well detected and consistent with both analyzes for both weak and strong actions. (ii) It is observed that the weak side of the structure, the $Y$ direction, is the one with the largest displacement, ie, depending on the angle of orientation of the building respect to the seismic action, this can be more intense, and when it affects the weak direction of the building, the expected performance will be worst. (iii) A high variability in the expected performance is obtained as a function of the orientation of the building, as shown in Table 5. (iv) There is a good relationship between the direction or angle where the highest seismic demand is presented for the fundamental period of the building, with the direction where the greatest displacement is obtained, especially in the linear zone. This relationship is decreasing or lost in the non-linear zone, which is attributed to the fact that in this area the building begins to have damages in some of its elements, which causes a change in its rigidity and increase its fundamental period, therefore, the seismic demand corresponding to its fundamental mode will no longer be the one that is being applied in the building. ( $v$ ) The displacements obtained (see Figure 9) can be used to perform an analysis of the expected damage. To do this, the method proposed in the RISK EU project (Milutinovic and Trendafiloski, 2003) or the simplified damage index that can be obtained directly from the capacity curve proposed by Pujades et al. (2015) for reinforced concrete structures and for steel structures (Diaz et al., 2017a and Diaz et al., 2017b) can be applied.

\section{Conclusions}

An alternative method to consider the seismic directionality effect has been proposed in this study.

- Analyzing the displacements obtained with both approaches that consider the effect of the orientation of the building respect to the accelerograms studied here, it is observed that the influence of orientation is relevant and significant since, in some cases, the expected responses can be increased up to $42 \%$ depending on the orientation of the building.

- $\quad$ The alternative method provides results with a good compatibility with those obtained using NLDA, which is more sophisticated and costly, so it is considered a simple and fast alternative that allows considering the directionality effect on buildings.

- The results of this research show that, the study of the directionality effect applied in the performance of steel buildings is of great interest in the earthquake engineering field and should be considered in future structural codes since it allows to improve the evaluation of the expected seismic damage in buildings.

\section{Acknowledgements}

This research has been partially funded by the Ministry of Economy and Competitiveness (MINECO) of the Spanish Government and by the European Regional Development Fund (FEDER) of the European Union (UE) through projects referenced as CGL2011-23621 and CGL2015-65913-P (MINECO/FEDER, UE). The first author holds a Ph.D. fellowships from the Universidad Juárez Autónoma de Tabasco (UJAT) and from the "Programa para el Desarrollo Profesional Docente, México" (PRODEP). The fifth author is supported by a Ph.D. scholarship grant from the "Instituto para la Formación y Aprovechamiento de Recursos Humanos" (IFARHU) and the "Secretaría Nacional de Ciencias, Tecnología e Innovación" (SENACYT) from the Government of Panama.

\section{References}

ANSI/AISC 341-10 (2010), Seismic Provisions for Structural Steel Buildings, American National Standard and American Institute of Steel Construction, pp. 356.

ANSI/AISC 358-10 (2010), Prequalified connections for special and intermediate steel moment frames for seismic applications, American National Standard and American Institute of Steel Construction, pp. 178.

ATC-40 (1996), Seismic evaluation and retrofit of concrete buildings, Applied Technology Council, Redwood City, California, pp 346.

Boore D.M. (2010), Orientation-independent, nongeometric-mean measures of seismic intensity from two horizontal components of motion. Bull. Seismol. Soc. Am., 100:1830-1835, doi: https://doi.org/10.1785/0120090400.

Boore D.M., Watson-Lamprey J.A. and Abrahamson, N.A. (2006), Orientation-independent measures of ground motion. Bull. Seismol. Soc. Am., 96:1502-1511, doi: https://doi.org/10.1785/0120050209. 
Bozorgnia Y., Abrahamson N.A., Al Atik L., et al. (2014), NGA-West2 research project. Earthq. Spectra, 30: 973-987, doi: https://doi.org/10.1193/072113EQS209M.

Carr A.J. (2002), Ruaumoko $2 \mathrm{~d}$ y $3 \mathrm{~d}$ - inelastic dynamic analysis program. University of Canterbury, New Zealand.

Chopra A. and Goel R. (2002), A modal pushover analysis procedure for estimating seismic demands for buildings. Earthq. Eng. Struct. Dyn., 31:561-582, doi: https://doi.org/10.1002/eqe.144.

Diaz S.A., Pujades L.G., Barbat A.H., Hidalgo-Leiva D.A. and Vargas Y.F. (2017a), Capacity, damage and fragility models for steel buildings. A probabilistic approach. Bulletin of Earthquake Engineering, doi: https://doi.org/10.1007/s1051.

Diaz S.A., Pujades L.G., Barbat, A.H., Vargas Y.F. and Hidalgo-Leiva D.A. (2017b), "Energy damage index based on capacity and response spectra", Eng. Struct., 152(1):424-436. doi: https://doi.org/10.1016/j.engstruct.2017.09.019.

FEMA 273 (1997), NEHRP guidelines for the seismic rehabilitation of buildings, Federal Emergency Management Agency, Washington, DC. pp. 435.

García-Soto A., Hong H. and Gomez R. (2012), Effect of the Orientation of Record on the Estimated Displacement Ductility Demand. Can. J. Civ. Eng., 39(4):362-373, doi: https://doi.org/10.1139//2012-010.

Hong H., Pozos-Estrada A. and Gómez-Martinez R. (2009), Orientation effect on ground motion measurement for Mexican subduction earthquakes. Earthq. Eng. Eng. Vib., 8:1-16, doi: https://doi.org/10.1007/s11803-009-8155-z.

Ibarra L.F., Medina R.A., Krawinkler H. (2005), Hysteretic models that incorporate strength and stiffness deterioration. Earthq. Eng. Struct. Dyn., 34:1489-1511, doi: https://doi.org/10.1002/eqe.495.

Kostinakis K., Athanatopoulou A. and Morfidis K. (2015), Correlation between ground motion intensity measures and seismic damage of 3D R/C buildings. Eng. Struct., 82:151-167, doi: https://doi.org/10.1016/j.engstruct.2014.10.035.

Kostinakis K. and Morfidis K. (2017), The impact of successive earthquakes on the seismic damage of multistorey 3D R/C buildings. Earthq. and Struct., 12:1-12, doi: https://doi.org/10.12989/eas.2017.12.1.001.

Lagaros N.D. (2010), The impact of the earthquake incident angle on the seismic loss estimation. Eng. Struct., 32:1577-89, doi: https://doi.org/10.1016/j.engstruct.2010.02.006.

Lee S., Goel S.C. and Chao S. (2004), Performance-based seismic design of steel moment frames using a target drift and yield mechanism. Proceedings of the 13th World Conference on Earthquake Engineering, Vancouver, Canada.

Leelataviwat S., Saewon W. and Goel S.C. (2009), Application of energy balance concept in seismic evaluation of structures. J. Struct. Eng., 135:113-121, doi: https://doi.org/10.1061/(ASCE)0733-9445(2009)135:2(113).

Lignos D.G. and Krawinkler H. (2011), Deterioration Modeling of Steel Components in Support of Collapse Prediction of Steel Moment Frames under Earthquake Loading. J. Struct. Eng., 137:1291-1302, doi: https://doi.org/10.1061/(ASCE)ST.1943-541X.0000376.

Lignos D.G. and Krawinkler H. (2013), Development and Utilization of Structural Component Databases for Performance-Based Earthquake Engineering. J. Struct. Eng., 139:1382-1394, doi: https://doi.org/10.1061/(ASCE)ST.1943-541X.0000646.

Mezzi M., Comodini F., Lucarelli M., et al. (2006), Pseudo-energy response spectra for the evaluation of the seismic response from pushover analysis. Proceedings of the 1st European Conferences on Earthquake Engineering and Seismology, Geneva, Switzerland.

Milutinovic Z. and Trendafiloski G. (2003), RISK-UE. An advanced approach to earthquake risk scenarios with applications to different European towns. WP04 Vulnerability of current buildings, pp. 111.

NTC-DF (2004), Norma Técnica Complementaria del Distrito Federal. Diseño por Sismos. Ciudad de México, Gaceta oficial de México. Tomo I y II, pp. 586.

Pinzón L.A., Hidalgo-Leiva D.A. and Pujades L.G. (2015), Medidas de intensidad sísmica independientes de la orientación del sensor: Aplicación a una base de datos con acelerogramas de Costa Rica, El Salvador y Nicaragua. Rev I+D Tecnológico, 11:55-67, doi: https://doi.org/10.13140/rg.2.1.2564.4240

Power M., Chiou B., Abrahamson N.A., et al. (2008), An overview of the NGA project. Earthq. Spectra, 24:3-21, doi: https://doi.org/10.1193/1.2894833.

Pujades L.G., Vargas-Alzate Y.F., Barbat A.H. and González-Drigo J.R. (2015), Parametric model for capacity curves. Bull. Earthq. Eng., 13:1347-1376, doi: https://doi.org/10.1007/s10518-014-9670-5.

Reyes-Salazar A., Valenzuela-Beltrán F., De León-Escobedo D., Bójorquez-Mora E, and López-Barraza A. (2016), Combination rules and critical seismic response of steel buildings modeled as complex MDOF systems. Earthq. and Struct., 10(1):211-238, doi: https://doi.org/10.12989/eas.2016.10.1.211.

Rigato A.B. and Medina R.A (2007), Influence of angle of incidence on seismic demands for inelastic single-storey structures subjected to bidirectional ground motions. Eng. Struct., 29:2593-2601, doi: https://doi.org/10.1016/j.engstruct.2007.01.008.

Satyarno I. (2000), Adaptive pushover analysis for the seismic assessment of older reinforced concrete buildings. Ph.D. Dissertation, University of Canterbury, Canterbury.

Vargas-Alzate Y.F., Barbat A.H., Pujades L.G. and Hurtado J.E. (2012), Probabilistic vulnerability assessment of a reinforced Concrete structure by using a 3-D model. Proceedings of the 15th World Conference on Earthquake Engineering (15WCEE). Lisboa, Portugal.

Vargas-Alzate Y.F., Pujades L.G., Barbat A.H., and Hurtado J.E. (2013), Capacity, fragility and damage in reinforced concrete buildings: A probabilistic approach. Bull. Earthq. Eng., 11(6):2007-2032, doi: https://doi.org/10.1007/s10518-013-9468-x.

Vargas-Alzate Y.F., Pujades L.G., Barbat A.H., Hurtado J.E., Diaz S.A. and Hidalgo-Leiva D.A. (2017), Probabilistic seismic damage assessment of reinforced concrete buildings considering directionality effects. Struct. Infrastruct. Eng., 2479(October):1-13. DOI: https://doi.org/10.1080/15732479.2017.1385089. 